\title{
Näin johdat Oy Minä Ab:tä
}

\author{
TOMI RANTAMÄKI \& TARJA SURAKKA (2013). \\ Työelämätaidot - Sinä oman työelämäsi johtajana. \\ Suomen Palkitsemiskeskus Oy ja Esimieskoulu Bosnet: Espoo. 199 s. \\ ISBN 978-952-93-2187-2
}

TYÖELÄMÄTAIDOT PYRKII kunnianhimoisesti kattamaan kaiken mahdollisen. Se on tarkoitettu tekijöidensä mukaanjokaiselle työssäkäyvälle tai töihin pyrkivälle- ja erityisesti juuri työelämään astuville.

Kirja alkaa henkilökohtaisesta osiosta, jossa tarkastellaan henkilökohtaisia arvostuksia, omaa toimintatapaa ja itsensä johtamista. Tästä siirrytään työyhteisön kuvaamiseen ja sitä seuraa koko työmarkkinakenttä aina työnhausta ja lainsäädännöstä erilaisten työnantajien ja yrittäjyyden esittelyyn.

Kun ottaa huomioon, että tuo kaikki yritetään mahduttaa kirjan 199 sivuun, on selvää, että jokaisesta aihealueesta tulee erittäin lyhyt, monesti lähes luettelonomainen.

Kirja tarjoaakin työelämään astuville napakoita listauksia ja hyvin koottuja asiakokonaisuuksia, esi- merkkeinä muun muassa työsopimusta ja työaikaa koskevat osiot. Myös viestinnän tarkastelu, aina yksityiskohtaisia sähköpostin kirjoittamisessa huomioitavia seikkoja myöten, tuntuu onnistuneelta ajatellen sekä kokonaisuutta että kohderyhmää.

Puheenvuoro yrittäjyyden näkökulmasta kirjan lopussa on kirjoitettu kannustavasti ja positiivisesti, joskin se lipsahtaa hieman ylilyönnin puolelle tekniikan kehitykselle asetettujen odotusten suhteen.

\section{HENGÄSTYTTÄVÄ LISTA ODOTUKSIA}

Valittu tyyli ja aihepiirin valtava laajuus eivät jätä tilaa asiaan syventymiselle saati sitten syvällisemmälle pohdinnalle. Yleisissä osioissa, jossa tarkastellaan työyhteisöä ja työmarkkinoita, valinta toimii hyvin. Henkilökohtaisessa osiossa se kääntyy itseään vastaan. 
Huomaan haukkovani henkeä alun henkilökohtaisessa osiossa, joka on kirjoitettu selvästi kirjan nimen virittämän odotuksen mukaisesti Oy Minä Ab:lle, jonka toimitusjohtajana itse kukin on. Osuus on lähtökohtaisesti kirjoitettu sisäisestä yrittäjyydestä käsin, jossa ihminen toimii työyhteisössä melko pitkälti samankaltaisin periaattein kuin yksityinen yrittäjä konsanaan.

Työntekijän omaa toimijuutta halutaan painottaa ja siihen kannustaa, mutta vaakakuppi heilahtaa auttamattomasti liiaksi henkilökohtaisen suuntaan. Tällöin esimiehen vastuu ja työyhteisön rooli jäävät kirjassa liian kevyiksi. Se tekee henkilökohtaisesta osuudesta sävyltään vaativan: työntekijän tulee olla luotettava, reilu, tunnollinen, yhteistyökykyinen, organisaatiotaitoinen, aloitteellinen, tehokas ja itseään kehittävä. Läkähdyttävään vaatimustasoon kuuluu vielä, että osaa arvioida itseään kaikkien mainittujen ominaisuuksien osalta.

Oman toiminnan arviointiin liittyvät osiot ovat varmasti vielä relevantteja jo pitkäänkin työssä olleelle, ja listauksia voisi hyvin hyödyntää esimerkiksi työyhteisöjen yhteisissä palavereissa. Myös tehokkuuden arvioinnin kysymykset tuntuisivat sopivan paremminkin esimiehen oman työn jäsentelyyn.

Vasta työelämään astuvalle osuus vaikuttaa varsin vaativalta. Kysymyksien edellyttämää itsetuntemusta tuskin on vasta-alkajalla ja taitaa tämän tasoinen ymmärrys puuttua monelta kokeneemmaltakin. Se laittaa helposti luun kurkkuun hieman heikommalla itsetunnolla varustetulle. Yksin pärjäämisen eetos vielä korostuu, kun kirjassa ei jostain syystä ole lainkaan esitelty työyhteisön tärkeitä yhteistyön rakenteita, kuten työsuojelu- ja luottamusmiestoimintaa.

\section{VERKKOTESTI KERTOO TYÖN SOPIVUUDEN}

Kirja antaa hyvän kokonaiskuvan työelämästä uudelle tulokkaalle. Konkreettiset, oikean elämän esimerkit ovat hyviä ja elävöittävät tekstiä. Fingerporin sarjakuvia on kiva lukea tekstin lomassa. Ehkäpä niiden tarkoitus on nimenomaan tuoda muuten niin tiukasti asiaan painottuvaan sisältöön keveyttä. Varsinaisen pintaa syvemmän tiedon tarvetta kirja ei tyydytä.

Teokseen liittyvät myös kehittelyvaiheessa olevat verkkosivut, joilla voi käydä tekemässä itsestään testin. Testin tuloksen pohjalta on tarkoitus arvioida nykyisen työnantajan sopivuutta. 60 peruskysymyksen vastauksella saa tuloksen, joka on nelikenttämuotoisena ja erikokoisine ympyröineen nopeasti kokonaisuuden hahmottava. Testi varmaankin palvelee nuoria perusasioiden hahmottamisessa, mikä lienee sen tarkoitus. Enemmän omia asioitaan pohtineelle ja kokeneemmalle työntekijälle testi tuskin tarjoaa uutta.

Omia tuloksia verrataan myös "sopivan vertailuryhmän tuloksiin". Vertailuryhmän laajuuden ja vertailukelpoisuuden arvioiminen ei kuitenkaan ole mahdollista, sillä ryhmä koostuu verkkotekstin mukaan kaikista kyselyyn vastanneista henkilöistä, joiden lukumäärä jää arvoitukseksi. Testin tekeminen vaatii kirjautumista ja käyttäjätilin luomista. Sivun lupaus, ettei joudu antamaan mitään sellaista tietoa, josta tekijä voitaisiin tunnistaa, romuttuu kättelyssä, kun ensimmäinen pakollinen tieto on oma sähköpostiosoite - kukapa testiä varten perustaisi uuden tilin?

Jaana Laukkarinen

DI, organisaatiokonsultti

Practitioner Certificate in Consulting and Change

(Tavistock Institute),

työnohjaaja (STOry)

Kehityspiikki Consulting Oy ja Awareness

\footnotetext{
"Yhteisöllisyys tuntuu olevan nykyään harvinaista herkkua monessa työpaikassa. Siksi sen soisi tässäkin, työelämään astuvalle tarkoitetussa kirjassa, saavan enemmän painoarvoa. Yhteisöllisyyden kolmiyhteys muodostuu esimiehestä (työnantajan edustajana), työyhteisöstä ja yksittäisestä henkilöstä. Teoksen painopiste jää liiaksi yksilön vastuulle; työntekijästä tulee oman onnensa seppä. Silloin tasapaino horjuu yhteisöllisyyden kustannuksella.

Itseensä luottavalle pärjääjälle kirja tarjoaa jäsentelyä oman työuran suunnitteluun ja tarkasteluun - heikommassa hapessa olevan se saattaa jättää ahdinkoon oman riittämättömyyden kanssa."
} 